\title{
RANCANG BANGUN MEDIA PEMBELAJARAN BERBASIS AUGMENTED REALITY UNTUK PEMBELAJARAN TEMATIK KELAS 5 SEKOLAH DASAR
}

\author{
Ariadie Chandra Nugraha ${ }^{1}$, Kemal Hakim Bachmid ${ }^{2}$, Khasanah Rahmawati ${ }^{3}$, Nadila Putri ${ }^{4}$, \\ Alifah Raihan Nur Hasanah ${ }^{5}$, Faishal Aziz Rahmat ${ }^{6}$ \\ 1,2,6 Jurusan Pendidikan Teknik Elektro, Fakultas Teknik, Universitas Negeri Yoyakarta \\ ${ }^{3,4}$ Jurusan Pendidikan Sekolah Dasar, Fakultas Ilmu Pendidikan, Universitas Negeri Yoyakarta \\ ${ }^{5}$ Jurusan Pendidikan Bahasa dan Sastra Indonesia, Fakultas Bahasa dan Seni, Teknik Universitas Negeri Yoyakarta \\ ${ }^{1}$ ariadie@ uny.ac.id*, ${ }^{2}$ kemalhakim.2019@student.uny.ac.id, ${ }^{3}$ khasanahrahmawati.2019@ student.uny.ac.id, \\ ${ }^{4}$ nadilaputri.2019@student.uny.ac.id, ${ }^{5}$ alifahraihan.2019@student.uny.ac.id, ${ }^{6}$ faishalaziz.2019@ student.uny.ac.id \\ *corresponding author
}

\begin{tabular}{|c|c|}
\hline ABSTRACT & Article Info \\
\hline $\begin{array}{l}\text { Cognitive development based on Piaget's theory in elementary school-aged } \\
\text { children is in the concrete operational and formal operational period, } \\
\text { children can think logically about something concrete, but if faced with } \\
\text { abstract problems they will tend to have difficulty During the COVID-19 } \\
\text { pandemic, education was held online which resulted in several problems. } \\
\text { Likewise with SDN Tegalmulyo which has several problems, such as } \\
\text { decreased student enthusiasm in learning, reduced understanding of the } \\
\text { material, and decreased student interest in learning. The purpose of this } \\
\text { research is to develop interesting and interactive learning media and to } \\
\text { assist teachers in delivering thematic learning materials. This program of } \\
\text { activities goes through a series of methods that include pre-activities } \\
\text { (licensing and needs analysis), implementation (programming guides, } \\
\text { program development, to the learning process) and post-activity } \\
\text { (evaluation). Feedback from application users for two months showed that } \\
70 \% \text { of students felt the learning atmosphere became more interesting and } \\
\text { fun; } 90 \% \text { of students feel more enthusiastic when learning to use PIN.AR; } \\
\text { and } 60 \% \text { of students want the PIN.AR application to be applied until the } \\
\text { end of the semester. Through the learning media, PIN.AR makes learning } \\
\text { more interactive, so that students can understand the material more easily, } \\
\text { can increase interest in learning, and can improve student understanding. }\end{array}$ & $\begin{array}{r}\text { Article history } \\
\text { Received: } \\
\text { November } 30^{\text {th }}, 2021 \\
\text { Revised: } \\
\text { November } 30^{\text {th }}, 2021 \\
\text { Accepted: } \\
\text { November } 30^{\text {th }}, 2021\end{array}$ \\
\hline \multicolumn{2}{|l|}{ ABSTRAK } \\
\hline $\begin{array}{l}\text { Perkembangan kognitif berdasarkan teori Piaget pada anak usia sekolah } \\
\text { dasar berada pada masa operasional konkret dan operasional formal, anak } \\
\text { dapat berpikir logis terhadap sesuatu yang bersifat konkret, tetapi jika } \\
\text { dihadapkan dengan permasalahan abstrak akan cenderung kesulitan. Selama } \\
\text { pandemi COVID-19, pendidikan diselenggarakan secara daring yang } \\
\text { mengakibatkan adanya beberapa permasalahan. Begitu pula dengan SDN } \\
\text { Tegalmulyo yang memiliki beberapa permasalahan, seperti menurunnya } \\
\text { antusias siswa dalam pembelajaran, berkurangnya pemahaman materi, serta }\end{array}$ & \\
\hline
\end{tabular}


menurunnya minat belajar siswa. Tujuan dari penelitian ini adalah untuk mengembangkan media pembelajaran yang menarik dan interaktif serta membantu guru dalam menyampaikan materi pembelajaran tematik. Program kegiatan ini melalui serangkaian metode yang mencakup prakegiatan (perizinan dan analisis kebutuhan), pelaksanaan (penyusunan panduan program, pembuatan program, hingga proses pembelajaran) dan pasca kegiatan (evaluasi). Umpan balik dari pengguna aplikasi selama dua bulan didapat hasil bahwa $70 \%$ siswa merasa suasana pembelajaran menjadi lebih menarik dan menyenangkan; $90 \%$ siswa merasa lebih semangat jika belajar menggunakan PIN.AR; serta $60 \%$ siswa menginginkan aplikasi PIN.AR diterapkan sampai akhir semester. Melalui media pembelajaran PIN.AR ini menjadikan pembelajaran lebih interaktif, sehingga siswa menjadi lebih mudah memahami materi, dapat meningkatkan minat belajar, dan dapat meningkatkan pemahaman siswa.

\section{PENDAHULUAN}

Perkembangan kognitif adalah tahapantahapan perubahan yang terjadi dalam rentang kehidupan manusia untuk memahami, mengolah informasi, memecahkan masalah dan mengetahui sesuatu. Jean Piaget mengemukakan tahapan-tahapan perkembangan kognitif pada anak yang menghubungkan tahapan perkembangan kematangan fisik dengan tahapan perkembangan kognitif. Tahapan-tahapan tersebut adalah tahap sensory motorik $(0-2$ tahun $)$, praoperasional $(2-7$ tahun), operasional konkret ( $7-11$ tahun) dan operasional formal (11 - 15 tahun) (Leny Marinda, 2020).

Sebagaimana menurut teori kognitif Piaget perkembangan kognitif pada anak usia sekolah dasar yang berusia $7-12$ berada pada masa operasional konkret dan operasional formal. Pada tahap ini anakanak sudah dapat memfungsikan akalnya untuk berpikir logis terhadap sesuatu yang bersifat konkret atau nyata. Pemikiran logis ini menggantikan pemikiran intuitif (naluri) dengan syarat pemikiran tersebut dapat diaplikasikan menjadi contoh-contoh yang konkret atau spesifik. Akan tetapi, kekurangan dari pada fase ini adalah ketika anak dihadapkan dengan pemasalahan yang bersifat abstrak (secara verbal) tanpa adanya objek nyata, maka ia akan mengalami kesulitan bahkan tidak mampu untuk menyelesaikannya dengan baik (Dian Andesti Bujuri, 2018).

Terlebih lagi pandemi global yang telah menyerang setiap sektor kehidupan membuat perubahan terhadap kegiatan sehari-hari. Contohnya dalam sektor pendidikan yang menerapkan metode pembelajaran e-learning atau daring sebagai upaya mengurangi penyebaran Covid-19. Pendidikan yang sebelumnya diselenggarakan secara luring dengan guru bertemu langsung dengan siswa, maka saat ini terpaksa harus belajar secara daring. Pembelajaran daring ini menyebabkan guru dan murid tidak dapat bertemu langsung. Akibatnya banyak siswa yang mengeluhkan minimnya interaksi dengan guru dikarenakan pembelajaran daring yang lebih banyak memberikan tugas kepada siswanya (Nur Azizah Rizki Astuti, 2020).

Hal ini disebabkan karena materi yang diberikan oleh guru kurang menarik perhatian para siswa, bagi mereka bermain jauh lebih menarik dibandingkan belajar. Ketika hal tersebut terjadi, maka akan terjadi kejenuhan pada pikiran siswa untuk belajar. Hal ini dapat menyebabkan kemalasan pada siswa untuk memahami materi karena kemasan materi yang sangat membosankan. Karena siswa belum 
terbiasa dengan kondisi Pembelajaran Jarak Jauh (PJJ) dan ilmu yang disampaikan belum diterima secara maksimal. Hal itu menjadi salah satu kendala bagi guru dan siswa. Adapun contoh kendalanya ialah tidak adanya pengawasan guru secara langsung untuk membimbing dan membina siswanya. (Afip Miftahul Basar, 2021). Meski pada usia 11 tahun dalam kelas lima SD/MI siswa memasuki tahap operasional formal di mana anak sudah bisa berpikir tentang objek yang bersifat abstrak dan berpikir secara kritis, namun tidak adanya pengawasan dari guru mengakibatkan siswa akan jarang membaca materi yang diberikan.

Hambatan-hambatan selama proses pembelajaran daring juga memengaruhi berjalannya proses pendidikan di Indonesia. Ketercapaian tujuan kurikulum serta pemahaman siswa terhadap materi yang diajarkan oleh guru, membuat pendidik harus dapat mengatasi dan meminimalisir hambatan tersebut (Siti Sabaniah, dkk, 2021). Berdasarkan hasil wawancara tim dengan guru kelas V SDN Tegalmulyo, mengatakan bahwa hambatan pembelajaran daring dirasakan pula pada Kegiatan Belajar Mengajar (KBM) di SDN Tegalmulyo, seperti tingkat pendalaman materi siswa hanya $60 \%$ karena tidak adanya bimbingan langsung dari guru. Pendapat guru pembelajaran yang dilakukan saat ini masih tergolong membosankan.

Siswa dan orang tua di SDN Tegalmulyo rata-rata telah menguasai dasar- dasar teknologi seperti mengoperasikan Microsoft Word, menggunakan aplikasi pesan singkat, dan aplikasi pendukung Pembelajaran Jarak Jauh (PJJ) dengan cukup baik. Akan tetapi, beberapa orang tua masih kurang peka dan tidak mendampingi serta membimbing anaknya dengan baik sehingga beberapa anak ada yang tertinggal pelajaran dan keterampilan dalam mengoperasikan teknologi tersebut. (Andri Anugrahana, 2020). Hal ini memengaruhi ketercapaian belajar siswa. Saat ini, guru cenderung hanya memberikan tugas-tugas dan materi dalam pembelajaran daring. Guru jarang melakukan tatap muka secara virtual di SDN Tegalmulyo sehingga menyebabkan pembelajaran menjadi membosankan dan tidak efektif bagi siswa.

Tujuan dari pelaksanaan kegiatan ini adalah untuk mengembangkan media pembelajaran yang menarik dan interaktif, membantu guru dalam menyampaikan materi pembelajaran tematik, serta membantu wali murid dalam mendukung proses pembelajaran siswa. Sehingga, dibutuhkan suatu inovasi media pembelajaran yang dapat membuat materi terkesan lebih menarik, interaktif, dan dapat dimainkan untuk menghindari kejenuhan dan menambah ketertarikan siswa pada materi yang akan dipelajari. Oleh karena itu, berdasarkan kebutuhan pendidikan, maka mitra bersama dengan tim menggunakan media pembelajaran yang komunikatif dan interaktif. Tim membuat suatu program kegiatan pengabdian kepada masyarakat yang dikemas dalam sebuah pelatihan penggunaan metode belajar tematik yang berbentuk Augmented Reality (AR). Media pembelajaran ini menggunakan sistem teknologi virtual untuk menarik minat belajar para siswa. Tema yang diberikan ialah tentang pembelajaran tematik di kelas 5 sekolah dasar.

\section{METODE}

Sekolah Dasar Negeri Tegalmulyo terletak di wilayah Desa Tegalmulyo, Kelurahan Pakuncen, Kecamatan Wirobrajan, Kota Yogyakarta, Provinsi Daerah Istimewa Yogyakarta merupakan sekolah ramah anak yang bangunannya layak pakai dan lengkap. 
Mayoritas penduduk di sekitar SDN Tegalmulyo merupakan masyarakat dengan ekonomi menengah.

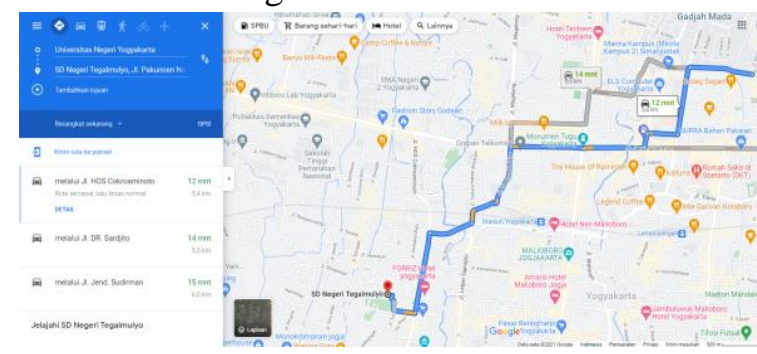

Gambar 1. Denah Lokasi Mitra dari Universitas

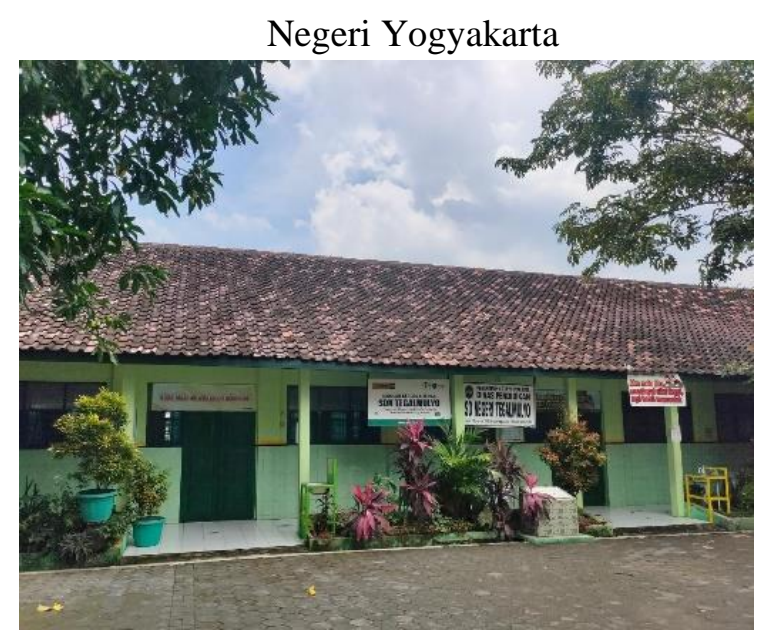

Gambar 2. Lokasi SDN Tegalmulyo

Kondisi pandemi Covid-19 ini membuat proses KBM atau Kegiatan Belajar Mengajar di SDN Tegalmulyo dilakukan secara daring. Hal tersebut menyebabkan beberapa kendala seperti menurunnya tingkat pemahaman materi, menurunnya minat belajar, dan menurunnya antusias belajar siswa karena pembelajaran dari guru yang membosankan serta tidak efektif. Maka dari itu, sekolah mitra melalui guru kelas menghendaki pendampingan tim peneliti untuk membuat media pembelajaran. Permintaan ini ditindaklanjuti tim peneliti dengan memilih salah satu bentuk aplikasi berbasis Augmented Reality (AR). Pemecahan masalah ini disesuaikan dengan kehendak sebagian besar siswa yang mengalami kejenuhan (rasa bosan) selama pembelajaran daring.

Pelaksanaan penelitian ini menggunakan metode ADDIE, yang mencakup lima tahap yaitu Analisis (Analysis), Desain (Design), Pembangunan (Development), Impelementasi dan Evaluasi (Evaluation).

\section{a. Tahap Analisis}

Pada tahap analisis, spesifikasi aplikasi media pembelajaran disusun peneliti bersama dengan mitra, yaitu guru-guru SDN Tegalmulyo. Diskusi bersama mitra pada tanggal 1 Juni 2021 membahas tentang keresahan mitra dan upaya menemukan pemecahan permasalahan tersebut. Hasil kesepakatannya yaitu diadakannya pelatihan dan pendampingan pembuatan media pembelajaran yang menarik bagi siswa. Tim menyusun rencana pelaksanaan pelatihan dan jadwal pendampingannya.

\section{b. Tahap Desain}

Pada tahap desain, dilakukan adalah penyusunan materi oleh guru kelas dalam aplikasi dan buku panduannya. Materi disesuaikan dengan buku pelajaran tematik yang digunakan oleh sekolah mitra. Dengan demikian, pengertian media pembelajaran tematik adalah segala sesuatu yang dapat menjadi perantara atau media dan dapat digunakan untuk mendukung kegiatan belajar siswa dari satu tema atau topik tertentu dan kemudian dielaborasi. Setelah itu, tim mulai mendampingi guru kelas dalam merancang dan membuat aplikasi per satu tema untuk diuji coba terlebih dahulu. Setelah hasil rancangan dicoba dan menunjukkan hasil yang sesuai tujuan, maka dilanjutkan untuk subtemasubtema berikutnya. Pada akhirnya media yang telah dibuat mitra dikenalkan kepada siswa.

\section{c. Tahap Development}

Pada tahap development, peneliti mengembangkan media pembelajaran berbasis Android dengan menerapkan teknologi Augemented Reality. Pengembangan aplikasi ini memanfaatkan Software Development Kit (SDK) Vuforia Augmented Reality sehingga fitur AR dapat diintegrasikan pada aplikasi.

\section{d. Implementasi}

Penyuluhan dilakukan sekali pada awal pelaksanaan program. Penyuluhan dilakukan secara daring melalui Google Meet oleh seluruh anggota tim dan guru SD terkait pada tanggal 3 
Juli 2021. Metode yang digunakan adalah penyuluhan tidak langsung melalui Google Meet. Penyuluhan ini dilakukan dengan pendekatan perorangan karena di SDN Tegalmulyo hanya memiliki satu kelas saja di setiap jenjang, sehingga hanya dilakukan oleh wali kelas dan tim pengabdi untuk memperkenalkan aplikasi yang telah dibuat. Teknik penyuluhan yang diterapkan oleh tim adalah teknik demonstrasi. Tim PIN.AR menjelaskan terlebih dahulu apa saja yang akan dilakukan dengan menggunakan aplikasi PIN.AR. Selanjutnya, tim menjelaskan fiturfitur dalam aplikasi tersebut serta bagaimana cara menggunakannya dengan demonstrasi langsung melalui Google Meet.

Pelatihan dilakukan secara daring menggunakan Google Meet pada tanggal 5 Juli 2021 dan dilakukan sekali karena telah diadakan penyuluhan sebelumnya. Pelatihan ini berisi tentang cara penggunaan aplikasi dalam pembelajaran. Hal tersebut meliputi penjelasan lebih lanjut tentang aplikasi PIN.AR beserta kelengkapan seperti, marker, buku panduan, dll. Pelatihan dilakukan dua hari sebelum tim peneliti masuk ke dalam kelas-kelas untuk melakukan pembelajaran daring sesuai kesepakatan jadwal dengan wali kelas. Hal ini bertujuan agar guru dapat memahami terlebih dahulu dan mengidentifikasi apabila ditemukan kendala atau kesulitan agar segera ditindaklanjuti oleh tim pengabdi.

Setelah pelatihan awal, dilaksanakan pendampingan sebanyak dua kali yaitu tanggal 3 dan 5 Juli 2021. Pertama, bersamaan dengan pelatihan dan yang kedua langsung dilaksanakan bersama orang tua serta siswanya. Hal ini dilakukan di setiap pembelajaran yang dimasuki oleh tim. Pendampingan ini dilakukan dengan metode demonstrasi terlebih dahulu yang kemudian dilanjutkan praktik bersama siswa dan orang tua siswa.

Selanjutnya, pembelajaran menggunakan program dilakukan sebanyak enam kali bersama tim peneliti pada hari Senin, Rabu, dan Jumat dalam rentan waktu 16 Agustus 2021 - 27 Agustus 2021. Pembelajaran dilakukan secara daring karena belum memungkinkan untuk tatap muka secara luring. Pembelajaran diikuti setengah dari total siswa yang ada di sekolah mitra karena adanya keterbatasan akses gawai.

\section{e. Tahap Evaluasi}

Evaluasi dilakukan secara online menggunakan Google Meet secara internal maupun bersama dengan sekolah mitra, dan dosen pendamping. Evaluasi dilakukan guna membahas keefektifan penggunaan aplikasi PIN.AR pada pembelajaran di SDN Tegalmulyo. Hasil evaluasi akan ditindaklanjuti untuk perbaikan kegiatan pembelajaran dan penyempurnaan aplikasi selanjutnya. Indikator keberhasilan pelaksanaan program ini adalah apabila pemahaman materi pembelajaran, keterlaksanaan pembelajaran tematik, tingkat kesenangan dan minat penggunaan aplikasi PIN.AR mencapai lebih dari $60 \%$ dari siswa yang mengakses aplikasi tersebut.

\section{HASIL DAN PEBAHASAN}

Aplikasi PIN.AR merupakan salah satu media pembelajaran yang interaktif dan komunikatif. Media pembelajaran ini dirancang untuk memudahkan siswa kelas 5 SD dalam memahami materi tematik yang ada di sekolah. Media pembelajaran ini dapat digunakan kapan saja dan di mana saja dengan tampilan objek gambar 3D yang dapat dilihat secara langsung oleh siswa.

\section{a. Aplikasi PIN.AR (Pintar Belajar dengan Augmented Reality)}

Aplikasi PIN.AR merupakan aplikasi berbasis Augmented Reality (AR) bertipe marker-based yang didesain sebagai media pembelajaran tematik kelas 5 SD. Aplikasi ini memiliki tampilan yang memudahkan siswa untuk memahami fitur di dalamnya. Aplikasi ini memuat gambar 3D yang menarik siswa serta memudahkan pemahaman siswa akan suatu materi atau gambar secara detail yang terwujud dalam gambar 3D. Wujudnya yang berupa gambar 3D ini dapat melengkapi buku pegangan siswa yang terbatas gambar 2D. 
Objek gambar 3D ini merupakan salah satu keunggulan aplikasi ini yang dapat melengkapi buku pembelajaran di sekolah yang hanya mencakup gambar 2D. Aplikasi ini dapat digunakan pada OS Android minimal 4.4 Kitkat yang mana bisa digunakan pada telepon pintar yang memiliki RAM rendah. Aplikasi PIN.AR ini sedang dalam proses verifikasi ke Google Play Store.

Tampilan awal aplikasi ini langsung disuguhi dengan tutorial penggunaan dan penjelasan fitur yang ada di dalamnya. Fitur yang tersedia ada 4, yakni: fitur scan marker, unduh buku marker, buku pedoman penggunaan dan tentang aplikasi (credits). Siswa dapat mengakses materi pembelajaran melalui fitur scan marker yang berbentuk logo "play". Saat ini penambahan materi pembelajaran hanya dapat dilakukan oleh pencipta atau internal, orang lain atau guru masih belum bisa menambahkan materi pada aplikasi ini. Setelah siswa menekan tombol play dan scan marker maka akan terlihat materi pembelajaran baik dalam bentuk 3D, video animasi, maupun video lagu sesuai dengan materi yang ada pada marker tersebut. Berikut elemen-elemen dalam aplikasi PIN.AR:

1) Augmented Reality (AR), merupakan gabungan antara dunia virtual berbentuk dua dimensi atau tiga dimensi dengan dunia nyata yang diproyeksikan dalam bentuk real-time pada saat aplikasi tersebut digunakan. Aplikasi ini berbasis marker based dengan desain user interface PIN.AR.

2) Marker, sebagai bentuk penanda pada dunia nyata untuk diproyeksikan melalui dunia maya.

3) Objek 3 dimensi, sebagai bentuk visualisasi dari materi yang akan dipelajari siswa.

4) Video animasi, berisi tentang materi yang dijelaskan untuk siswa.

5) Kamera, sebagai alat scan marker yang akan menampilkan hasil dari augmented reality.

6) Android atau gawai, sebagai penampil hasil proyeksi dunia maya. aplikasi:

Berikut bagian-bagian yang ada dalam

1) Tombol play AR, untuk scan marker yang kemudian menampilkan objek tiga dimensi atau video animasi mengenai pembelajaran tematik.

2) Tombol help atau bantuan, pengguna dapat mengunduh modul buku panduan penggunaan aplikasi PIN.AR dan marker dalam bentuk buku digital.

3) Tombol download, pengguna dapat mengunduh marker untuk mengakses materi pembelajaran yang sudah disediakan.

4) Tombol credits PIN.AR, berisi credits pembuatan augmented reality untuk pembelajaran tematik serta ucapan terima kasih.

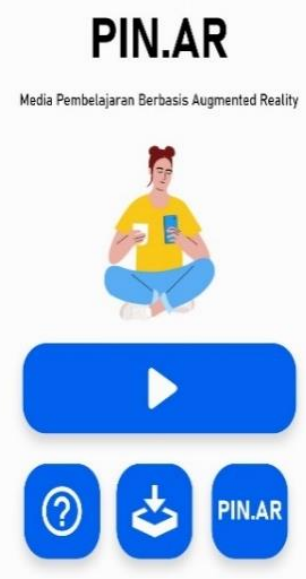

Gambar 3. Home Aplikasi PIN.AR

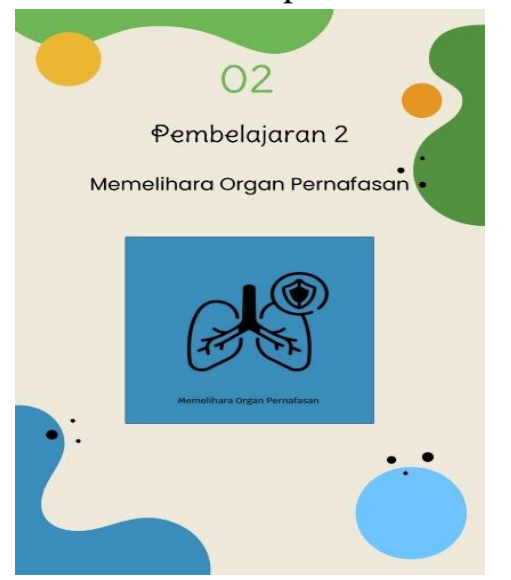

Gambar 4. Marker aplikasi PIN.AR 


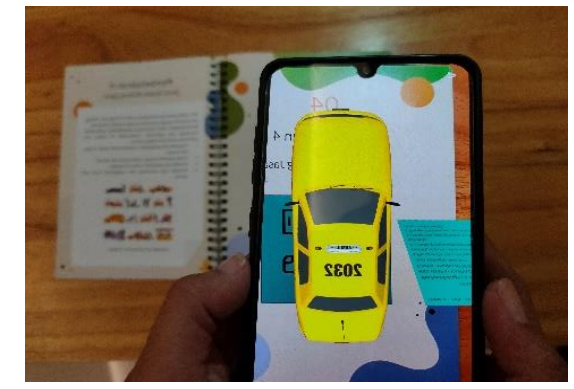

Gambar 5. Bentuk 3D Aplikasi PIN.AR

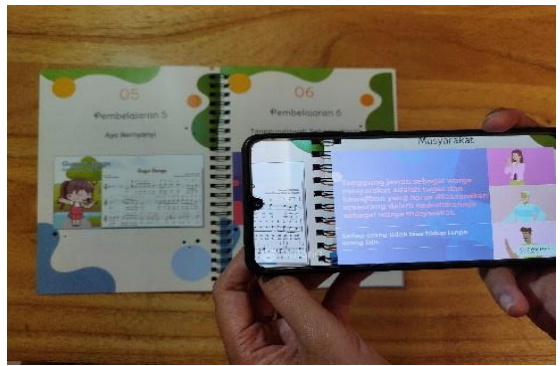

Gambar 6. Bentuk Video Animasi Aplikasi

PIN.AR

\section{b. PIN.AR sebagai Media Pembelajaran Tematik di SDN Tegalmulyo}

Aplikasi PIN.AR merupakan salah satu perantara tersebut. PIN.AR membantu siswa memahami materi pembelajaran tematik karena di dalamnya ada visualisasi materi yang diajarkan di sekolah. Hal ini memudahkan siswa dalam belajar dan menggambarkan sesuatu. Berdasarkan hasil wawancara tim dengan guru dan siswa, kebermanfaatan PIN.AR sebagai media pembelajaran tematik di SDN Tegalmulyo adalah dapat meningkatkan pemahaman terhadap materi pembelajaran tematik, dapat meningkatkan minat belajar para pelajar di Indonesia, dapat meningkatkan antusias belajar siswa, dan dapat mengenal media pembelajaran baru yang menarik dan interaktif sehingga membantu guru dalam proses pembelajaran.

Berdasarkan deskripsi di atas, media pembelajaran PIN.AR menjadi alat bantu dan bahan kegiatan pembelajaran yang berfungsi untuk mengefektifkan komunikasi antara guru dan murid dalam suatu proses pembelajaran. Media pembelajaran digunakan agar siswa dapat memperoleh pengetahuan, keterampilan, dan sikap. Media pembelajaran juga dapat membantu siswa agar lebih efektif dan efisien dalam menerima materi pembelajaran.

Manfaat dari media pembelajaran PIN.AR yang sejalan dengan pendapat Musfiqon (2012: 31) yaitu:

1) Memberikan siswa rangsangan untuk belajar.

2) Menjadikan pembelajaran lebih efektif dan efisien.

3) Dapat menyampaikan pesan dengan tepat.

4) Mengatasi kebutuhan dan permasalahan siswa belajar.

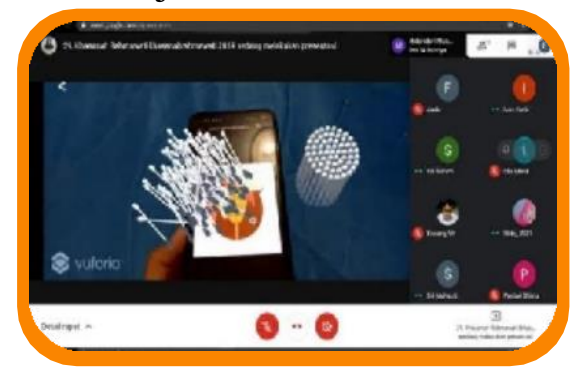

Gambar 7. Proses Pembelajaran dengan PIN.AR

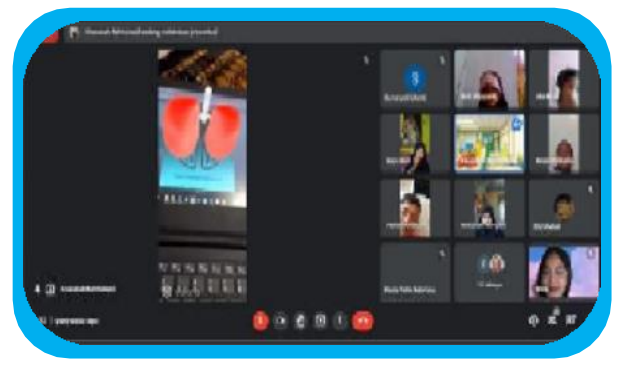

Gambar 8. Proses Pembelajaran dengan

PIN.AR

Guru juga merasa terbantu dalam menyampaikan materi pembelajaran pada siswa sehingga pembelajaran menjadi lebih menarik dan efektif. Namun terdapat evaluasi dan saran pada media pembelajaran PIN.AR yang telah dibuat, seperti program kamera aplikasi untuk scan marker yang terkadang mengalami kendala kelambatan proses menampilkan hasil augmented reality objek tiga dimensi atau video animasi dan aplikasi yang masih dalam proses pengunggahan pada Google Play Store untuk disegerakan. 
Kebermanfaatan media pembelajaran

Berdasarkan hasil wawancara PIN.AR untuk orang tua atau wali murid yaitu untuk membantu mendampingi anaknya dalam belajar, sehingga orang tua bisa ikut mengontrol proses belajar anaknya.

Tabel 1. Perbandingan sebelum dan sesudah adanya media pembelajaran PIN.AR

\begin{tabular}{lll}
\hline \multicolumn{2}{c}{ Sebelum } & \multicolumn{2}{c}{ Sesudah } \\
\hline $\begin{array}{l}\text { Guru kelas mengeluhkan penurunan tingkat } \\
\text { belajar setelah adanya media pembelajaran }\end{array}$ & $\begin{array}{l}\text { Siswa selama proses pembelajaran } \\
\text { daring. }\end{array}$ & PIN.AR terjadi peningkatan minat dan \\
Berkurangnya jumlah pengumpul tugas yang & Meningkatnya jumlah siswa yang \\
rata-rata hanya 3 dari 25 siswa. & mengumpulkan penugasan dengan tepat \\
& waktu yaitu 15 siswa. \\
Tingkat pendalaman materi siswa yang hanya & Tingkat pendalaman dan pemahaman \\
$60 \%$ karena tidak adanya bimbingan langsung & materi siswa yang meningkat karena \\
dari guru. & adanya bantuan media pembelajaran. Hal \\
& ini dibuktikan dengan meningkatnya \\
& jumlah siswa yang mengumpulkan \\
& penugasan serta hasil penilaian post test \\
& dari tim pada siswa yang memuaskan. \\
\hline
\end{tabular}

Penerapan PIN.AR di SDN Tegalmulyo sudah dilakukan secara berkala, mulai dari pengenalan aplikasi, penyuluhan, dan pelatihan sampai pada penggunaanaplikasi pada saat pembelajaran. Umpan balik dari penggunaan aplikasi selama duabulan didapat hasil bahwa $70 \%$ siswa merasa suasana pembelajaran menjadi lebih menarik dan menyenangkan; 90\% siswa merasa lebih semangat jika belajar menggunakan PIN.AR; serta 60\% siswa menginginkan aplikasi PIN.AR diterapkan sampai akhir semester. Berdasarkan hasil wawancara tim dengan siswa, mereka mampu mengerjakan penugasan dari guru dengan mudah ketika adanya bantuan media pembelajaran, siswa juga lebih memahami pembelajaran tematik karena ada contoh konkret yang divisualisasikan melalui bentuk tiga dimensi atau video animasi, dan siswa juga dengan siswa dan guru berikut perbandingan kondisi sebelum dan sesudah adanya media pembelajaran PIN.AR. dari tim pada siswa yang memuaskan.

mengalami antusias serta minat belajar yang tinggi. Maka pelaksanaan program PIN.AR dalam proses pembelajaran tematik dapat dikatakan berhasil.

Upaya keberlanjutan pengembangan media pembelajaran PIN.AR ialah sebagai berikut: (1) Pengembangan aplikasi PIN.AR dengan berbagai fitur tambahan, seperti latihan soal dan quiz untuk siswa; (2) Pengunggahan aplikasi ke Google Playstore, untuk memudahkan siswa dalam pengunduhan aplikasi; (3) Bekerja sama dengan Dinas Pendidikan Kota Yogyakarta, dilakukan untuk mendukung keberlanjutan program tak hanya di sekolah mitra, tetapi juga sekolah-sekolah lain; (4) Perluasan penggunaan aplikasi PIN.AR, dalam rangka menjadikan aplikasi PIN.AR sebagai salah satu solusi media pembelajaran interaktif di masa pandemi maupun pasca pandemi 
dengan tampilan tiga dimensi yang memudahkan pemahaman siswa.

\section{SIMPULAN}

Berdasarkan hasil yang diperoleh, dapat disimpulkan bahwa aplikasi PIN.AR dapat menambah wawasan ilmu pengetahuan dan teknologi, serta dapat meningkatkan minat belajar dan pemahaman siswa dalam pembelajaran. Aplikasi ini digunakan oleh mitra sebagai upaya peningkatan pemahaman siswanya terhadap pembelajaran tematik di kelas 5 SDN Tegalmulyo. Sebelum menggunakan aplikasi ini, para siswa memiliki tingkat pemahaman materi yang menurun pada saat pembelajaran diselenggarakan secara daring. Setelah menggunakan aplikasi ini, hasil data siswa menunjukkan terjadinya perubahan positif pada siswa. Siswa menjadi lebih mudah memahami materi serta pembelajaran dapat lebih interaktif dikarenakan media pembelajaran yang digunakan. Dengan ketercapaian tersebut, aplikasi ini dapat dikembangkan dalam jangkauan jenjang dan materi yang lebih luas, sehingga dapat dijadikan sebagai salah satu media pembelajaran yang efektif untuk siswa. Perluasan penggunaan aplikasi PIN.AR dengan sekolah-sekolah lain juga sebagai salah satu solusi media pembelajaran interaktif di masa pandemi maupun pasca pandemi dengan tampilan tiga dimensi maupun video animasi yang memudahkan pemahaman siswa.

\section{DAFTAR RUJUKAN}

Anugrahana, Andri. 2020. Hambatan, Solusi, dan Harapan: Pembelajaran Daring Selama Masa Pandemi Covid-19 Oleh Guru Sekolah Dasar. Scholaria: Jurnal Pendidikan dan Kebudayaan. 10(3): 286. https://ejournal.uksw.edu/scholaria/article /view/4033. Diakses 15 Februari 2021.

Astuti, Nur Azizah Rizki. 2020. KPAI Ungkap Kendala Anak Saat Belajar Daring: Kuota-Beban Tugas Tinggi.
Artikel. https://news.detik.com/berita/d5067692/kpai-ungkap-kendala-anak-saatbelajar-daring-kuota-beban-tugas-tinggi.

Diakses 14 September 2021.

Basar, Miftahul Afip. 2021. Problematika Pembelajaran Jarak Jauh Pada Masa Pandemi Covid-19. Jurnal Ilmiah Pendidikan, 2 (1). https://media.neliti.com/media/publicatio ns/331350-problematika-pembelajaranjarak-jauh-pad-f67e8dbd.pdf diakses pada 15 Oktober 2021.

Bujuri, Dian Andesta. 2018. Analisis Perkembangan Kognitif Anak Usia Dasar dan Implikasinya dalam Kegiatan Belajar Mengajar. Jurnal Ilmu Pendidikan, 9(1). https://ejournal.almaata.ac.id/index.php/L ITERASI/article/view/720 diakses pada 19 Oktober 2021.

Dwiwati, D. M, N. Suparta, dan I G. S. A. Putra. 2016. Dampak Teknik Penyuluhan Focus Group Discussion (FGD) terhadap Perubahan Pengetahuan, Sikap dan Penerapan pada Penyuluh dan Peternak Sapi Bali di Bali. Jurnal Ilmiah Peternakan, 19(2). http://khodijahismail.com/wpcontent/uploads/2015/07/6.- Metoda-danTeknik-Penyuluhan.pdf diakses pada 15 Agutus 2021.

Ina Magdalena, Dea Kiki Yestiani, Puspitasari. 2020. Perkembangan Belajar Siswa. Al junrejo- Batu : Literasi Nusantara. , 2(2): 305. Diakses 05 Agustus 2021.

Magdalena, I., Yestiani, D. K., \& Puspitasari, P. 2020. Rendahnya PerkembanganMutu Hasil Belajar Siswa Sekolah Dasar Dengan AdanyaPembelajaran Online. Jurnal Edukasi dan Sains. 2(2): 292-305. https://ejournal.stitpn.ac.id/index.php/ 
edisi/article/view/1022. Diakses 05 Agustus 2021.

Marinda, Leny. 2020. Teori Perkembangan Kognitif Jean Piaget dan Problematikanya pada Anaka Usia Sekolah Dasar. Jurnal Kajian Peremuan \& Keislaman, 13(1). https://media.neliti.com/media/publicatio ns/340203-teori-perkembangan-kognitifjean-piaget-00d2756c.pdf diakses pada 19 Oktober 2021.

Meilani, G.R. 2018. Membangun Aplikasi Augmented Reality dengan Unity. Surabaya: CV. Garuda Mas Sejahtera.

Sabaniah, S., Ramdhan, F. D., \& Rohmah K. S. 2021. Peran Guru dalam Pelaksanaan Pembelajaran Jarak Jauh di Tengah Wabah Covid - 19. Jurnal Ilmiah Pendidikan, 2(1). https://media.neliti.com/media/publica tions/331335-peran-guru-dalampelaksanaan-pembelajarac0e69d57.pdf diakses pada 15 Oktober 2021.
Suarsana, I M., \& Mahayukti, G. A. (2013). Pengembangan E-modul BerorientasiPemecahan Masalah untuk Meningkatkan Keterampilan Berpikir Kritis Mahasiswa. Jurnal Nasional Pendidikan Teknik Informatika (JANAPATI), 193-200. https://ejournal.undiksha.ac.id/index.p hp/JPI/article/view/2171/0 diakses pada 9 Oktober 2021.

Sugihartini, Nyoman. 2016. Strategi Pembelajaran

(Pendekatan pembelajaran inovatif disertai denganAplikasi Pembelajaran Bidang Teknologi Informasi dan Komunikasi). Singaraja: Undiksha Press.

http://eprints.umg.ac.id/3059/3/BAB\%20 II.pdf (Diakses hari Kamis, 7 Oktober 2021. Pukul 08.05 WIB).

http://eprints.umm.ac.id/61689/3/BAB\%20II.pd f (Diakses hari Kamis, 7 Oktober2021. Pukul 08.05 WIB). 